Communication

\title{
Increased Conversion to 2,4,6-Triarylpyrylium Salt: Aldol Cyclotrimerization of Acetophenone in $\mathrm{BMImPF}_{6}$ lonic Liquid
}

\author{
Po-Neng Chuang ${ }^{\mathrm{a}, \mathrm{b}}$ (莊博能), Tsao-Dong $\mathrm{Wu}^{\mathrm{a}, \mathrm{c}}$ (吳朝棟) and Ling-Kang $\mathrm{Liu}^{\mathrm{a}, \mathrm{c} *}$ ( 劉陵崗) \\ anstitute of Chemistry, Academia Sinica, Nankang, Taipei 115, Taiwan, R.O.C. \\ ${ }^{\mathrm{b}}$ Department of Chemistry, National Central University, Jhongli, Taoyuan 32001, Taiwan, R.O.C. \\ ${ }^{\mathrm{c}}$ Department of Chemistry, National Taiwan University, Taipei 106, Taiwan, R.O.C.
}

\begin{abstract}
Substituted acetophenone 1 in $\mathrm{BMImPF}_{6}$ ionic liquid, heated at $120{ }^{\circ} \mathrm{C}$ for $24 \mathrm{~h}$, produces $\beta$-methylchalcone 2, triarylbenzene 3 , and triarylpyrylium salt $4 . \mathrm{BMImPF}_{6}$ catalyzes the self-aldol condensation of $\mathbf{1}$, whose cyclotrimerization gives an increased conversion to $\mathbf{4}$ at the expense of $\mathbf{3}$ normally obtained from the cyclotrimerization of $\mathbf{1}$ in common organic solvent.
\end{abstract}

Keywords: Ionic liquid; Acetophenone; Self-aldol condensation.

Room temperature ionic liquids (RTILs), a class of organic salts that melt below $100{ }^{\circ} \mathrm{C}$, are often used as solvent in homogeneous catalysis in order to take advantages of negligible vapor pressure, high thermal stability, tunable polarity, etc. ${ }^{1}$ The highly polar nature of RTILs likely increases the life time of a charge-separated transition state during reaction. Seddon et al. found that, employing $\mathrm{EMImAl}_{2} \mathrm{Cl}_{7}$ melts in the Friedel-Crafts acetylation reaction of naphthalene, the thermodynamically unfavored 1isomer became the major product whereas the thermodynamically favored 2-isomer exhibited only a $2 \%$ yield (Scheme I). ${ }^{2}$ Xiao et al. also reported that the Pd-catalyzed Heck arylation reaction of electron rich olefins and aryl halides in $\mathrm{BMImBF}_{4}$ produced essentially the less common branched products, not the linear ones (Scheme II). ${ }^{3}$ These results suggested that as media of reactions, RTILs could shift the reaction to follow the more ionic pathways.

Conventionally aldol condensation reactions were performed in organic solvents. ${ }^{4}$ In 2002, Mehnert et al. started investigation of the aldol condensation reactions employing imidazolium ionic liquid phases treated with aqueous solution of $\mathrm{NaOH}$ as the catalyst. ${ }^{5}$ Later, piperidine $^{6}$ and L-proline ${ }^{7}$ in RTIL, respectively, were studied extensively. Also appeared were the pyrrolidine-functionalized ionic liquids for the aldol condensation reactions. ${ }^{8}$ Up to the present time, the base catalyzed aldol condensation reactions in ionic liquids have been documented.
Scheme I Friedel-Crafts acetylation reaction of naphthalene<smiles>CC(=O)c1ccc2ccccc2c1</smiles>

2-isomer

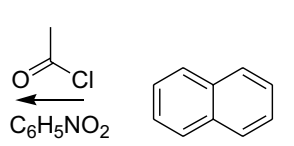

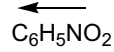

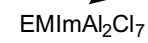

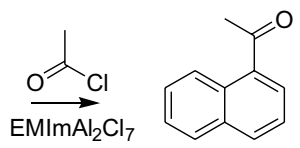

1-isomer
Scheme II Pd-catalyzed Heck arylation reaction of olefin and aryl halide

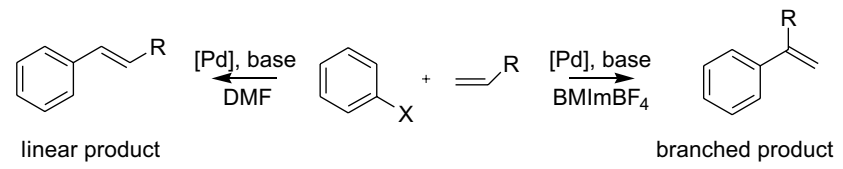

In this report we wish to present the observation of aldol cyclotrimerization of acetophenone mediated by $\mathrm{BMImPF}_{6}$, without the addition of base. The cyclotrimerization was found to produce in substantial amounts the 2,4,6-triarylpyrylium salts ${ }^{9}$ in addition to the more familiar 1,3,5-triarylbenzene. That is in sharp contrast to the results of conventional preparation of 1,3,5-triarylbenzene in organic phase with Lewis acid catalyzed aldol cyclocondensation. ${ }^{4,10-12}$

Herein substituted acetophenone $\mathbf{1}$ and hydrophobic $\mathrm{BMImPF}_{6}$ ionic liquid were mixed well in a round bottomed flask equipped with a condenser and the solution

*Corresponding author. Fax: +886-2-27831237; E-mail: liuu@chem.sinica.edu.tw 
stirred and maintained constantly at $120^{\circ} \mathrm{C}$. During the reaction the mixture became increasingly viscous, even solidified. After $24 \mathrm{~h}$, the reaction was stopped and the reaction mixture extracted with $\mathrm{Et}_{2} \mathrm{O}$ for 3 times. The combined $\mathrm{Et}_{2} \mathrm{O}$ fractions were rotary evaporated and the crude purified with $\mathrm{SiO}_{2}$ column chromatography. In addition to unused acetophenone, $\beta$-methylchalcone 2 and triarylbenzene 3 were obtained (Scheme III, with conversions). Without $\mathrm{BMImPF}_{6}$ ionic liquid, only acetophenone was recovered after being heated at $120{ }^{\circ} \mathrm{C}$ for $24 \mathrm{~h}$. With hydrophilic BMImBr ionic liquid, there was no reaction either.

Scheme III Aldol condensation reaction of acetophenone in $\mathrm{BMImPF}_{6}$

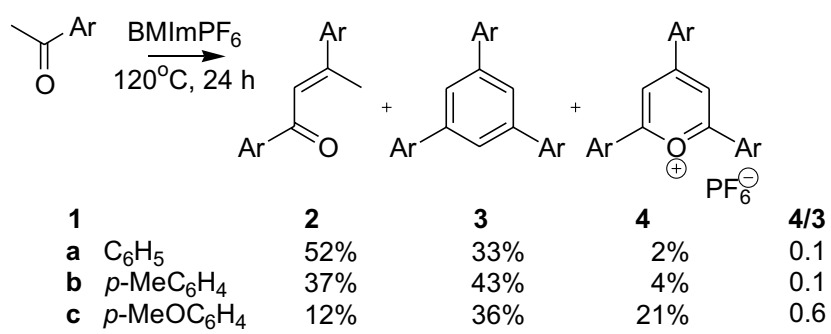

The reaction mixture after $\mathrm{Et}_{2} \mathrm{O}$ extraction was then added with just enough amounts of EtOH in order to keep the ionic liquid in solution. After standing for $24 \mathrm{~h}$, triarylpyrylium $\mathrm{PF}_{6}$ salt 4 precipitated and the salt was characterized by NMR $\left({ }^{1} \mathrm{H},{ }^{13} \mathrm{C},{ }^{19} \mathrm{~F}\right.$, and $\left.{ }^{31} \mathrm{P}\right)$ and other analytical methods. In the ${ }^{1} \mathrm{H}$ NMR spectra of $\mathbf{4 b}$, for example, the singlet resonance at $\delta 9.06$ was assigned to the pyrylium ring protons, downfield shifted by $1.3 \delta$ units when compared to the singlet resonance at $\delta 7.73$ assigned to the inner benzene ring protons of $\mathbf{3} \mathbf{b}$, attributable to the highly electron-withdrawing nature of cationic pyrylium.

Because in the above experiments, $\mathbf{2}$ is a dimeric intermediate of $\mathbf{1}$ and both $\mathbf{3}$ and $\mathbf{4}$ are trimers of $\mathbf{1}$, it is interesting to look into more details the ratios of conversion on $\mathbf{4 a} / \mathbf{3} \mathbf{a}, \mathbf{4 b} / \mathbf{3 b}$, and $\mathbf{4 c / 3} \mathbf{c}$, at $c a 0.1,0.1$, and 0.6 , respectively. A more electron releasing substituent at $\mathbf{1}$ favors the production of 4 .

Jing et al. detailed the treatment of $\mathbf{1}$ with $p$-tolylsulfonyl acid and a catalytic amount of $\mathrm{SnCl}_{4}$ in $\mathrm{C}_{5} \mathrm{H}_{11} \mathrm{OH}$ to produce 3 in good yields without noticing $4 .{ }^{11}$ Alternatively the strategy of Lewis acid promoted cyclotrimerization of acetyl aromatics lead to 1,3,5-triarylbenze formation $\left(100 \%\right.$ yield) with conditions of $\mathrm{TiCl}_{4}(1.5 \mathrm{eq}), o-$
$\mathrm{C}_{6} \mathrm{H}_{4} \mathrm{Cl}_{2}, 180{ }^{\circ} \mathrm{C}$ for $24 \mathrm{~h}$; no 2,4,6-triarylpyrylium formation being indicated. ${ }^{12}$ Obviously the aldol cyclotrimerization reaction of $\mathbf{1}$ in organic solvents produces mainly $\mathbf{3}$; similar reaction in hydrophobic $\mathrm{BMImPF}_{6}$ produces substantially the ionic 4 , in addition to the neutral 3.

Though formulated as the $\mathrm{PF}_{6}$ salt, the anions of $4 \mathrm{a}-\mathrm{c}$ were not $100 \% \mathrm{PF}_{6}^{-}$, nonetheless. In the ${ }^{31} \mathrm{P}$ NMR spectra, 4a-c exhibited a septuplet at $c a \delta-145$ with ${ }^{1} J_{\mathrm{PF}}=711 \mathrm{~Hz}$ (assigned to $\mathrm{PF}_{6}{ }^{-}$) plus a singlet at $c a \delta-1.8$ (assigned to $\mathrm{H}_{3} \mathrm{PO}_{4}$ ) with intensities varying from sample to sample. In the ${ }^{19}$ F NMR spectra, 4a-c exhibited a doublet at $c a \delta-70$ with ${ }^{1} J_{\mathrm{PF}}=711 \mathrm{~Hz}$ (assigned to $\mathrm{PF}_{6}^{-}$) and a singlet at $c a \delta$ -147 (assigned to HF) with varying intensity, too. These NMR data suggested existence of the $\mathrm{H}_{2} \mathrm{O}-\mathrm{HF}-\mathrm{P}_{2} \mathrm{O}_{5}$ phase system in that $\mathrm{PF}_{6}{ }^{-}$and $\mathrm{H}_{3} \mathrm{PO}_{4}$ are likely equilibrated by hydrolysis, ${ }^{13}$ leading to the existence of fluorides in the system.

Hydrophobic $\mathrm{BMImPF}_{6}$ ionic liquid was regarded as thermally stable with a thermal decomposition temperature at $349{ }^{\circ} \mathrm{C}$ as shown in TGA studies. ${ }^{14}$ However, Kosmulski et al. reported that wet spots could be observed in crucibles of TGA after conditioning bmimPF 6 at $200{ }^{\circ} \mathrm{C}$ for $10 \mathrm{~h}$, i.e. the thermal decomposition temperature based on fast TGA scans does not imply a long term thermal stability. ${ }^{15}$ In our experiments, the ionic liquid layer after the reaction was also examined with ${ }^{1} \mathrm{H}$ NMR, whose spectrum revealed two different sets of BMIm peaks. One set of signals was identical to that of $\mathrm{BMImPF}_{6}$; the other set associated with anion(s) other than $\mathrm{PF}_{6}{ }^{-}$. The $\mathrm{PF}_{6}{ }^{-}$anions of the $\mathrm{BMImPF}_{6}$ ionic liquid at $120{ }^{\circ} \mathrm{C}$ in the long term presence of $\mathbf{1}$ must have degraded to produce at least tracing fluorides and $\mathrm{PF}_{5}$ to catalyze the aldol condensation of $\mathbf{1}$.

The $\mathrm{PF}_{6}{ }^{-}$anion has been known to be weakly coordinating. ${ }^{16}$ Gilbert et al. reported that in ionic liquids with weakly coordinating anions, tracing water exists as $\mathrm{H}_{3} \mathrm{O}^{+}$, not $\mathrm{H}_{2} \mathrm{O}^{17}$. Under the constraint, the ionic liquids would allow aldol addition followed by slow $\mathrm{H}_{2} \mathrm{O}$ elimination. Loh et al. observed that L-proline in $\mathrm{BMImPF}_{6}$ catalyzes aldol reactions in that $\mathrm{H}_{2} \mathrm{O}$ elimination products could not be observed within $20 \mathrm{~h}^{7(\mathrm{~b})}$ In line with the slower $\mathrm{H}_{2} \mathrm{O}$ elimination steps, a mechanism is proposed in Scheme IV for the production of 4 in $\mathrm{BMImPF}_{6}$ ionic liquid. A depronated and activated $\mathbf{1}$ adds to a second molecule of $\mathbf{1}$ to form the intermediate structure $\mathbf{A}$, which after elimination of $\mathrm{H}_{2} \mathrm{O}$ equivalent, results in $\mathbf{2}$. When $\mathbf{2}$ is depronated and activated, it adds to a third molecule of $\mathbf{1}$ to form intermediate structure 
Scheme IV Proposed mechanism for aldol cyclotrimerization of acetophenone derivatives in $\mathrm{BMImPF}_{6}$

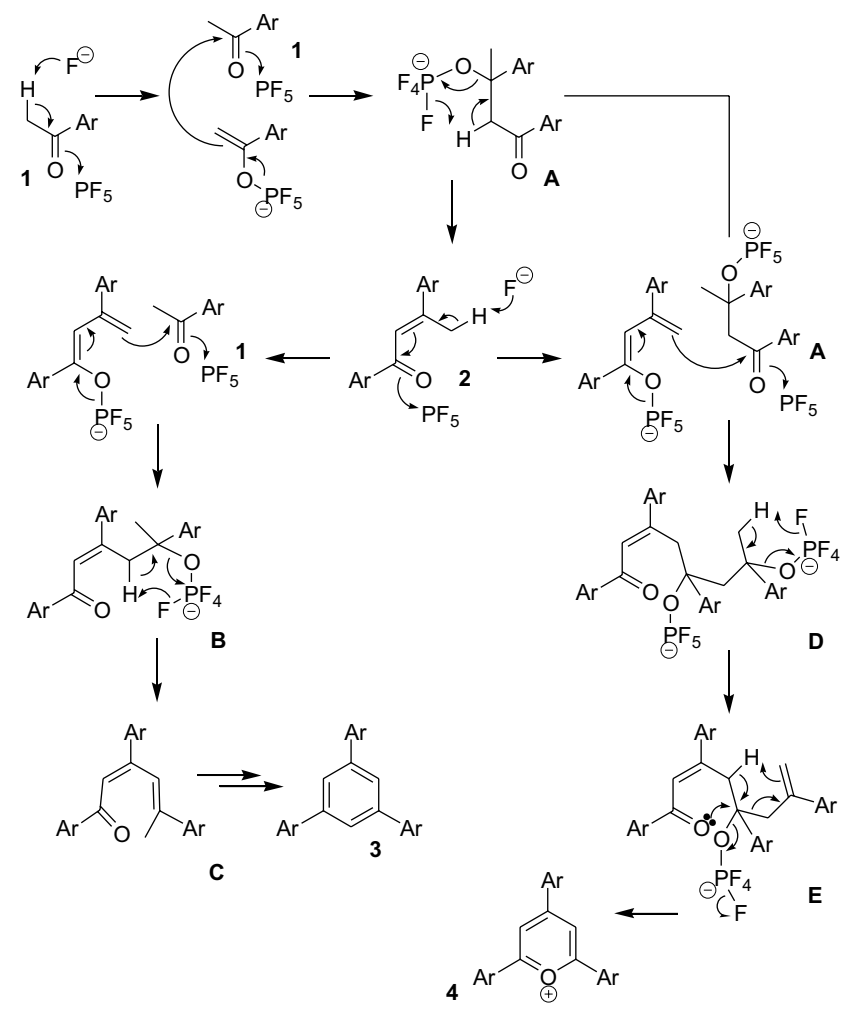

B. Similar elimination gives $\mathbf{C}$ whose dehydration yields the cyclotrimeric product $\mathbf{3}$. Alternatively, if the deprotonated and activated $\mathbf{2}$ adds to structure $\mathbf{A}$ (accumulated because of the slower elimination step); the outcome changes to intermediate structures $\mathbf{D}$ then $\mathbf{E}$, in that the formation of a remote double bond is followed by its extrusion via the 6-membered cyclic transition state ${ }^{18}$ to yield the cyclotrimeric product 4 . The polymeric materials found in these reactions is consistent to the extrusion of $\mathrm{ArCMe}=\mathrm{CH}_{2}$.

As the imidazolium cations were spectators only, the same chemistry also worked with other dissolving $\mathrm{PF}_{6}$ salts. The $\mathrm{NaPF}_{6}$ dissolution in $\mathbf{1}$ was similarly investigated at $120{ }^{\circ} \mathrm{C}$ for $24 \mathrm{~h}$ in that the aldol cyclotrimerization reaction also proceeded. The conversion results after the same $\mathrm{Et}_{2} \mathrm{O}$ and $\mathrm{EtOH}$ workup were given in Scheme V. Noted were the increasing conversions of both $\mathbf{3}$ and $\mathbf{4}$ in the $\mathrm{NaPF}_{6}$ studies, presumably the reactive dissolution of $\mathrm{NaPF}_{6}$ in $\mathbf{1}$ gave high ion concentrations in the mixture and the conversion was seemingly faster than in $\mathrm{BMImPF}_{6}$. To avoid solidification of mixtures in flask, a combination of
Scheme V Aldol condensation reaction of acetophenone derivatives upon dissolution of $\mathrm{NaPF}_{6}$

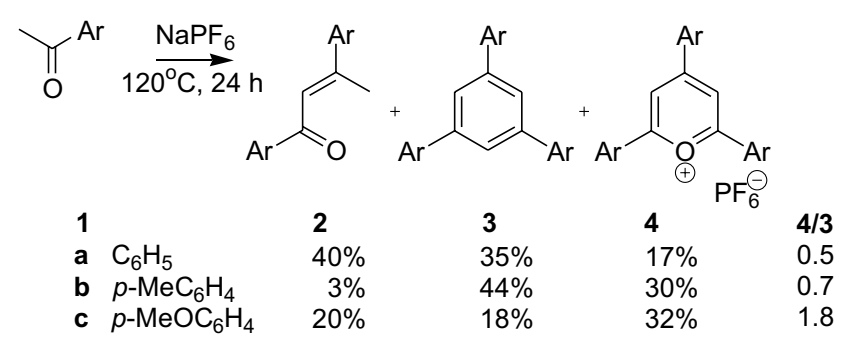

$\mathbf{1 b} / \mathrm{NaPF}_{6} / \mathrm{BMImPF}_{6}(10 \mathrm{mmol} / 10 \mathrm{mmol} / 2 \mathrm{~mL})$ was also heated at $120{ }^{\circ} \mathrm{C}$ for $24 \mathrm{~h}$. In this case the $4 / 3$ ratio was found to be 1.6 , higher than 0.1 with only $\mathrm{BMImPF}_{6}$ and 0.7 with only $\mathrm{NaPF}_{6}$.

As a conclusion, the $\mathrm{BMImPF}_{6}$ ionic liquid mediated aldol cyclotrimerization of acetophenones 1 are $\mathrm{PF}_{5}$ catalyzed processes with a slow $\mathrm{H}_{2} \mathrm{O}$ elimination step; the cyclotrimerization of $\mathbf{1}$ in $\mathrm{BMImPF}_{6}$ ionic liquid and the cyclotrimerization of $\mathbf{1}$ upon reactive dissolution of $\mathrm{NaPF}_{6}$ in $\mathbf{1}$ exhibit noted conversion to the trimeric product of 2,4,6-triarylpyrylium salts 4 at the expense of 1,3,5-triarylbenzenes 3 .

\section{EXPERIMENTAL SECTION}

General procedures

Into a single-neck round-bottomed flask $(50 \mathrm{~mL})$ was introduced a stirring bar, substituted acetophenone (50 mmol) and bmimPF 6 (10 mL, $58 \mathrm{mmol})$, then fitted with a condenser, before the temperature of the mixture being raised and kept at $120^{\circ} \mathrm{C}$ for $24 \mathrm{~h}$ with constant stirring. After this, the mixture was cooled down to room temperature and quenched by extraction with $\mathrm{Et}_{2} \mathrm{O}(3 \times 15 \mathrm{~mL})$. The combined $\mathrm{Et}_{2} \mathrm{O}$ fractions were rotary evaporated. The crude was purified by $\mathrm{SiO}_{2}$ column chromatography, eluting with 1:10 $\mathrm{Et}_{2} \mathrm{O} /$ hexanes, to recover $\mathbf{1}$, yield oily $\mathbf{2}$ and solid $\mathbf{3}$. Compound 2 slowly solidified upon standing at room temperature. Compound 3 was recrystallized from $\mathrm{CH}_{2} \mathrm{Cl}_{2}$ / EtOH. The remaining ionic liquid layer was added with just enough amounts of $\mathrm{EtOH}$ and let stand for $24 \mathrm{~h}$ to give precipitate 4. Conversions are shown in Scheme III. Similarly, acetophenone reaction with $\mathrm{NaPF}_{6}(10 \mathrm{mmol}$ each) was carried out with conversions shown in Scheme V.

\section{Characterization data}

2a yellow solid (CAS 495-45-4), mp $56{ }^{\circ} \mathrm{C} ;{ }^{1} \mathrm{H}$ NMR $\left(\mathrm{CDCl}_{3}\right): \delta 7.8-7.5(\mathrm{~m}, 10 \mathrm{H}), 7.2(\mathrm{~s}, 1 \mathrm{H}), 2.6(\mathrm{~s}, 3 \mathrm{H})$; MS- 
EI: $m / z$ 222. ${ }^{10(\mathrm{~b})}$ 3a white solids (CAS 612-71-5), mp 168-169 ${ }^{\circ} \mathrm{C} ;{ }^{1} \mathrm{H}$ NMR $\left(\mathrm{CDCl}_{3}\right): \delta 7.77$ (s, 3H), 7.68-7.70 (m, 6H), 7.45-7.49 (m, 6H), 7.36-7.39 (m, 3H); MS-EI: $m / z$ $306 .{ }^{19}$ 4a fluorescing yellow powder, ${ }^{1} \mathrm{H}$ NMR ( $\left.\mathrm{d}^{6}-\mathrm{DMSO}\right)$ : $\delta 9.17(\mathrm{~s}, 2 \mathrm{H}), 8.59-8.61(\mathrm{~m}, 6 \mathrm{H}), 7.86-7.89(\mathrm{~m}, 3 \mathrm{H}), 7.77-$ $7.82(\mathrm{~m}, 6 \mathrm{H}) ;{ }^{13} \mathrm{C}$ NMR (d $\left.-\mathrm{DMSO}\right): \delta 170.09,165.13$, $135.13,134.99,132.49,130.00,129.83,129.80,129.11$, 128.78, 115.20; ${ }^{19} \mathrm{~F}$ NMR (d $\left.\mathrm{d}^{6}-\mathrm{DMSO}\right): \delta-69.5$ (d, $J=711$ $\mathrm{Hz}) ;{ }^{31} \mathrm{P}$ NMR (d $\left.\mathrm{d}^{6} \mathrm{DMSO}\right): \delta-144.9$ (septet, $J=711 \mathrm{~Hz}$ ); MS-EI: $m / z 309\left([\mathrm{M}-\mathrm{A}]^{+}\right){ }^{20}$

2b yellow solid (CAS 36201-04-4), mp 57-58 ${ }^{\circ} \mathrm{C} ;{ }^{1} \mathrm{H}$ NMR $\left(\mathrm{CDCl}_{3}\right)$ : $\delta 7.92(\mathrm{~d}, 2 \mathrm{H}), 7.49(\mathrm{~d}, 2 \mathrm{H}), 7.26(\mathrm{~d}, 2 \mathrm{H})$, 7.22 (d, 2H), 7.17 (s, 1H), 2.61 (s, 3H), 2.41 (s, 3H), 2.39 (s, 3H); MS-EI: $m / z 250 .{ }^{10(b)} \mathbf{3 b}$ white solids (CAS 5044643-0), mp 167-168 ${ }^{\circ} \mathrm{C} ;{ }^{1} \mathrm{H}$ NMR $\left(\mathrm{CDCl}_{3}\right): \delta 7.73$ (s, 3H), 7.59 (d, $J=8 \mathrm{~Hz}, 6 \mathrm{H}), 7.27$ (d, $J=8 \mathrm{~Hz}, 6 \mathrm{H}), 2.41$ (s, 9H); MS-EI: $m / z$ 348. ${ }^{19(\mathrm{c})}$ 4b fluorescing yellow powder, ${ }^{1} \mathrm{H}$ NMR (d $\mathrm{d}^{6}$-Acetone): $\delta 9.06(\mathrm{~s}, 2 \mathrm{H}), 8.46-8.54(\mathrm{~m}, 6 \mathrm{H}), 7.60$ $7.65(\mathrm{~m}, 6 \mathrm{H}), 2.53-2.54(\mathrm{~m}, 9 \mathrm{H}) ;{ }^{13} \mathrm{C}$ NMR $\left(\mathrm{d}^{6}-\mathrm{DMSO}\right): \delta$ $169.15,163.79,146.80,146.16,130.43,129.94,129.34$, $128.48,126.20,113.03,21.40,21.36 ;{ }^{19} \mathrm{~F}$ NMR $\left(\mathrm{d}^{6}-\right.$ DMSO): $\delta-72.8(\mathrm{~d}, J=711 \mathrm{~Hz}),-147.6 ;{ }^{31} \mathrm{P}$ NMR $\left(\mathrm{d}^{6}-\right.$ DMSO): $\delta-1.8,-144.9$ (septet, $J=711 \mathrm{~Hz}$ ); MS-EI: $\mathrm{m} / z$ $351\left([\mathrm{M}-\mathrm{A}]^{+}\right) .^{21}$ 2c yellow solid (CAS 16197-83-4), mp 84-85 ${ }^{\circ} \mathrm{C} ;{ }^{1} \mathrm{H}$ NMR $\left(\mathrm{CDCl}_{3}\right): \delta 7.9-7.8(\mathrm{~m}, 8 \mathrm{H}), 7.1(\mathrm{~s}, 1 \mathrm{H})$, $3.8(\mathrm{~s}, 6 \mathrm{H}), 2.5(\mathrm{~s}, 3 \mathrm{H})$; MS-EI: $m / z 282 .^{10(\mathrm{~b})} \mathbf{3 c}$ white solids (CAS 7509-20-8), mp 139-141 ${ }^{\circ} \mathrm{C} ;{ }^{1} \mathrm{H}$ NMR $\left(\mathrm{CDCl}_{3}\right): \delta$ $7.65(\mathrm{~s}, 3 \mathrm{H}), 7.62(\mathrm{~d}, 6 \mathrm{H}, J=9.3 \mathrm{~Hz}), 7.02(\mathrm{~d}, 6 \mathrm{H}, J=9.3$ $\mathrm{Hz}), 3.85$ (s, 9H); MS-EI: $\mathrm{m} / z$ 396. ${ }^{19(\mathrm{c})} 4 \mathrm{c}$ fluorescing orange crystals, ${ }^{1} \mathrm{H}$ NMR (d $\mathrm{d}^{6}$-DMSO): $\delta 8.82$ (s, 2H). 8.618.64 (d, 2H), 8.50-8.53 (d, 4H), 7.29-7.32 (m, 6H), 3.96$3.98(\mathrm{~m}, 9 \mathrm{H}) ;{ }^{13} \mathrm{C}$ NMR (d $\mathrm{d}^{6}$-DMSO): $\delta 167.37,165.21$, $164.41,161.40,132.25,130.39,124.12,121.00,115.15$, 110.25, 55.97, 55.83; ${ }^{19} \mathrm{~F}$ NMR (d ${ }^{6}$-DMSO): $\delta-70.2(\mathrm{~d}, J=$ $711 \mathrm{~Hz}),-147.6 ;{ }^{31} \mathrm{P} \mathrm{NMR}\left(\mathrm{d}^{6}-\mathrm{DMSO}\right): \delta-144.9$ (septet, $J=$ $711 \mathrm{~Hz})$; MS-EI: $m / z 399\left([\mathrm{M}-\mathrm{A}]^{+}\right){ }^{10(\mathrm{~b})}$

Received February 19, 2008.

\section{REFERENCES}

1. (a) Chowdhury, S.; Mohan, R. S.; Scott, J. L. Tetrahedron 2007, 63, 2363-2389. (b) Wasserscheid, P.; Welton, T. Ionic Liquids in Synthesis; Wiley-VCH: Weinheim, Germany, 2003. (c) Rogers, R. D.; Seddon, K. R. Ionic Liquids as Green Solvents: Progress and Prospects; ACS Symp. Ser., 856; ACS: Washington, D. C., 2003. (d) Handy, S. T. Chem.
Eur. J. 2003, 9, 2938-2944. (e) Rogers, R. D.; Seddon, K. R. Ionic Liquids: Industrial Applications for Green Chemistry; ACS Symp. Ser., 818; ACS: Washington, D. C., 2002. (f) Dupont, J.; De Souza, R. F.; Suarez, P. A. Z. Chem. Rev. 2002, 102, 3667-3691. (g) Sheldon, R. Chem. Commun. 2001, 2399-2407. (h) Wasserscheid, P.; Keim, W. Angew. Chem. Int. Ed. 2000, 39, 3772-3789. (i) Welton, T. Chem. Rev. 1999, 99, 2071-2083.

2. Adams, C. J.; Earle, M. J.; Roberts, G.; Seddon, K. R. Chem. Commun. 1998, 2097-2098.

3. Mo, J.; Xu, L.; Xiao, J. J. Amer. Chem. Soc. 2005, 127, 751760 .

4. (a) Modern Aldol Reactions; Mahrwald, R. Eds.; WileyVCH: Weinheim, Germany, 2004; Vol. 1 and 2. (b) March, J.; Smith, M. Advanced Organic Chemistry: Reactions, Mechanisms, and Structure, $5^{\text {th }}$ ed.; Wiley: New York, 2001. (c) Evans, D. A. Aldrichimica Acta 1982, 15, 23-32.

5. (a) Mehnert, C. P.; Dispenziere, N. C.; Schlosberg, R. H. US Patent 6,552,232,B2, 2003. (b) Mehnert, C. P.; Dispenziere, N. C.; Cook, R. A. Chem. Commun. 2002, 1610-1611.

6. Davey, P. N.; Forsyth, S. A.; Gunaratne, H. Q. N.; Hardacre, C.; McKeown, A.; McMath, S. E. J.; Rooney, D. W.; Seddon, K. R. Green Chem. 2005, 7, 224-229.

7. (a) Cordova, A. Tetrahed. Lett. 2004, 45, 3949-3952. (b) Loh, T.-P.; Feng, L.-C.; Yang, H.-Y.; Yang, J.-Y. Tetrahed. Lett. 2002, 43, 8741-8743. (c) Kotrusz, P.; Kmentova, I.; Gotov, B.; Toma, S.; Solcaniova, E. Chem. Commun. 2002, 2510-2511.

8. Luo, S.; Mi, X.; Zhang, L.; Liu, S.; Xu, H.; Cheng, J.-P. Tetrahedron 2007, 63, 1923-1930.

9. Balaban, T. S.; Balaban, A. T. In Science of Synthesis: Houben-Weyl Methods of Molecular Transformations; Thomas, E. J.; Ed.; Georg Thieme Verlag: Stuttgart, Germany, 2003; Vol. 14.

10. (a) Bao, C.; Lu, R.; Jin, M.; Xue, P.; Tan, C.; Xu, T.; Liu, G.; Zhao, Y. Chem. Eur. J. 2006, 12, 3287-3294. (b) RuizGuerrero, R.; Cardenas, J.; Bautista, L.; Vargas, M.; VazquezLabastida, E.; Salmon, M. J. Mex. Chem. Soc. 2006, 50, 114-118.

11. Jing, X.; Xu, F.; Zhu, Q.; Ren, X.; Yan, C.; Wang, L.; Wang, J. Synth. Commun. 2005, 35, 3167-3171.

12. Cao, X.-Y.; Liu, X.-H.; Zhou, X.-H.; Zhang, Y.; Jiang, Y.; Cao, Y.; Cui, Y.-X.; Pei, J. J. Org. Chem. 2004, 69, 60506058.

13. Ames, D. P.; Ohashi, S.; Callis, C. F.; Van Wazer, J. R. J. Am. Chem. Soc. 1959, 81, 6350-6357.

14. Huddleston, J. G.; Visser, A. E.; Reichert, W. M.; Willauer, H. D.; Broker, G. A.; Rogers, R. D. Green Chem. 2001, 3, 156-164.

15. Kosmulski, M.; Gustafsson, J.; Rosenholm, J. B. Thermo- 
chim. Acta 2004, 412, 47-53.

16. Krossing, I.; Raabe, I. Angew. Chem. Int. Ed. 2004, 43, 2066-2090.

17. Thomazeau, C.; Olivier-Bourbigou, H.; Magna, L.; Luts, S.; Gilbert, B. J. Am. Chem. Soc. 2003, 125, 5264-5265.

18. To form oligomeric materials. See Barker, S. A.; Riley, T. J. Chem. Soc., Perkin Trans. I 1972, 809-812.

19. (a) Kakeya, M.; Fujihara, T.; Kasaya, T.; Nagasawa, A. Organometallics 2006, 25, 4131-4137. (b) Berthiol, F.; Kondolff, I.; Doucet, H.; Santelli, M. J. Organomet. Chem.
2004, 689, 2786-2798. (c) Tagliatesta, P.; Floris, B.; Galloni, P.; Leoni, A.; D’Arcangelo, G. Inorg. Chem. 2003, 42, 7701 7703.

20. Funston, A.; Kirby, J. P.; Miller, J. R.; Pospisil, L.; Fiedler, J.; Hromadova, M.; Gal, M.; Pecka, J.; Valasek, M.; Zawada, Z.; Rempala, P.; Michl, J. J. Phys. Chem. 2005, A109, 10862-10869.

21. Katritzky, A. R.; Zakaria, Z.; Lunt, E. J. Chem. Soc., Perkin Trans. I 1980, 1879-1987. 